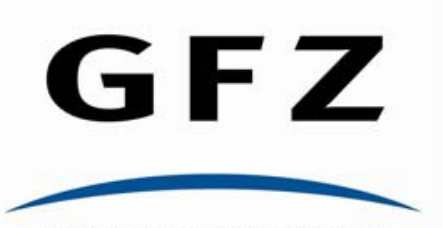

Helmholtz-Zentrum

POTS D A M

Originally published as:

Nardone, L., Manzo, R., Galluzzo, D., Pilz, M., Carannante, S., Di Maio, R., Orazi, M. (2020): Shear wave velocity and attenuation structure of Ischia island using broad band seismic noise records. - Journal of Volcanology and Geothermal Research, 401, 106970.

DOI: https://doi.org/10.1016/j.jvolgeores.2020.106970 


\title{
Shear wave velocity and attenuation structure of Ischia island using broad band seismic noise records
}

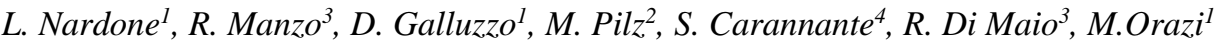 \\ 1Istituto Nazionale di Geofisica e Vulcanologia, Sez. di Napoli, Osservatorio Vesuviano \\ 2 GFZ German Research Center for Geosciences, Helmholtz str. 7, 14467 Potsdam, Germany \\ 3 DISTAR - Università di Napoli Federico II \\ 4Istituto Nazionale di Geofisica e Vulcanologia, Sez. di Milano
}

\begin{abstract}
In volcanic areas, accurate localization of earthquakes requires detailed velocity and, possibly, attenuation models, taking into account wide lithological variability and high geothermal gradients. Ischia island (Campania region, Italy) is a seismically-active volcano recently affected by a Mw 3.9 event (Casamicciola, August 21, 2017, $1 \mathrm{~km}$ depth). Due to the lack of a specific velocity model, the earthquakes occurred on the island were localized using the one developed for the nearby Campi Flegrei caldera. The aim of this work is the definition of a mean representative 1D shear-wave velocity (Vs) and attenuation (Q) model of the shallower crust (up to $2 \mathrm{~km}$ depth) of Ischia. Seismic noise array and spectral ratios techniques were applied to broad band seismic signals recorded by temporary and permanent networks updated after the August 2017 earthquake. The values of both shear-wave velocity (Vs) and quality factor (Q) are realistic, with $\mathrm{Q}$ values comparable with those obtained for Campi Flegrei and Stromboli volcanic areas. By taking into account stratigraphic information from deep wells and ultrasonic measurements of velocity on granite and trachytic lava samples, a geological interpretation of the resulting velocity model is provided. Such a model can have significant implications for understanding the dynamics of a volcano, mainly those leading to seismic activity.
\end{abstract}

\section{Keyword: Ischia volcanic island, Shear wave velocity model, Seismic attenuation, Seismic noise.}

\section{Introduction}

Generally, the wide lithological variability and the strong geothermal gradients that characterize highly heterogeneous areas, such as volcanic districts, make difficult to apply seismic noise data analysis techniques adopted for the definition of 1D velocity models (Foti et al., 2017). For this reason, the use of standard methods must be pursued in a weighted manner, highlighting the limits when applied to complex geological contexts. In the last two decades, array-processing techniques applied to seismic noise recorded by small array (maximum aperture of the array of about one hundred meters) have been usedto characterize the surface-wave propagation (La Rocca et al., 2010; Poggi and Fäh, 2010; Galluzzo et al., 2015) or the site effects (Picozzi et al., 2009; Maresca et al., 2014; Famiani et al., 2020). In volcanic areas, where lithological heterogeneities at the small scale are mostly expected, array techniques have been used to extract information about the shallow subsoil structure (i.e. estimation of the S-wave velocity profile) (Nardone and Maresca, 2011; Petrosino et al., 2012; Nardone et al., 2017). The wide use of these techniques to study the earth structures or the properties of the wave field suffers from limitations at low frequency in relation to the array aperture.

A seismic array (sometimes called "seismic antenna") consists of a set of seismic sensors, with common GPS time base, located closely enough in space so that arriving seismic waveforms and seismic noise can be correlated between adjacent sensors (Havskov and Ottemöller, 2010). The main difference between a seismic array and a local network of seismic stations is mainly linked to data analysis techniques, and, as a matter of principle, it's possible to manage a network of seismic stations as an array and vice versa. The high signal coherence, that most array data processing techniques require, determines important constraints on array geometry (that is usually regular), spatial extension and data quality (Schweitzer et al., 2012). Generally, 
the greater the aperture of the array, the lower the wave number that can be measured. The distances between the seismometers define the position of the side lobes in the transfer function of the array and the large solvable wave number. The minimum distance between the sensors therefore defines the resolution for large wave numbers, meaning that the lower the average distance, the greater the wave number of a resolvable seismic phase will be (Henstridge 1979; Di Giulio et al., 2006; Wathelet et al., 2008). An important hypothesis to consider when arrays based on microtremor survey methods are used, is that all sensors of the array must sample the same geology, that is areas where the geology can be approximated by a 1D layered earth.

The present work is based on the use of an array much larger than those used for small scale imaging, in order to explore Earth volumes with linear surface dimensions of the order of 8 - $10 \mathrm{~km}$ and thickness of $2 \mathrm{~km}$. For this purpose, we considered the monitoring seismic network of the volcanic island of Ischia, upgraded after the $\mathrm{M}_{\mathrm{w}} 3.9$ earthquake, as a large array (maximum aperture equal to $\sim 8.5 \mathrm{~km}$ ) with a non-regular geometry to obtain the Vs velocity and attenuation profile in the first $2 \mathrm{~km}$ depth by applying the $\underline{\boldsymbol{S P}}$ atial $\underline{\boldsymbol{A} u t o} \underline{\mathrm{C} o r r e l a t i o n}$ (SPAC) (Aki, 1957) method to the seismic noise recorded by the broad-band network stations. Our choice to use the SPAC/ESAC (Extended SPatial Autocorrelation, Ohori et al., 2002) methods in a volcanic contest, where different geological structures linked to the main morpho-structural resurgent block of M. Epomeo are present (Sbrana et al., 2018 and reference therein), grounds on the results obtained by Strollo et al. (2015) and Vassallo et al. (2018), which support the assumption that the large-scale structure below the island is nearly 1D, if the minimum wavelength of the seismic network is considered. Strollo et al. (2015) applied the seismic noise cross-correlation technique, accomplished by frequency-time analysis and non-linear inversion of dispersion data. They found 1D velocity models in the first $1.5 \mathrm{~km}$ depth along 13 paths that cross the island with different orientation, with maximum path distance equal to $7.0 \mathrm{~km}$. The velocity models are relatively similar and the differences are included in the $30 \%$ of variability. Whilst Vassallo et al. (2018), by three small seismic arrays (maximum aperture equal to $400 \mathrm{~m}$ ) located in the northern sector of the island, reconstructed three shear wave velocity profile up to $400 \mathrm{~m}$ depth highlighting that the major lithological differences were in the first $100 \mathrm{~m}$.

In addition, the idea to derive both velocity and attenuation model of the Ischia island by a single analysis is based on a recent study by Boxberger et al. (2017), who presented a method for calculating the effective attenuation structure at a site by adding a few and successive calculation steps to the SPAC description. Still, the anelasticity of a volcanic medium causes considerable wave-energy loss during propagation due to seismic scattering and absorption. Simply stated, the quality factor $Q$ describes the energy loss of a single wavelength due to the various mechanisms of attenuation at various scales. The intrinsic attenuation $Q_{\text {int }}$ can depend on rock type (Assefa et al., 1999), state of the material (Del Pezzo et al., 1995), temperature (Roth et al., 2000), thermoelasticity (Aki, 1980; Frankel et al., 1990), effects of fluids (Haong-Trong, 1983), and frictional heating (Fukuchi et al., 2005). On the other hand, scattering attenuation $Q_{\text {scatt }}$, which is generally considered to be frequencydependent (Aki and Chouet, 1975), represents the loss of energy of a direct wave caused by reflection, refraction, and conversion into shear energy due to the medium heterogeneity and/or to the occurrence of fractures and cracks. Generally, the effective attenuation $Q_{\text {eff }}$ can be thought of as the sum of these two components: $Q_{\text {eff }}{ }^{-1}=Q_{\text {int }}{ }^{-1}+Q_{\text {scatt }}{ }^{-1}$. Therefore, even if the attenuation below a site could be considered as an independent parameter from the velocity structure, both parameters can be obtained by a single analysis (Boxberger et al., 2017).

In the Campanian volcanic district, velocity and attenuation models are available for Vesuvius and Campi Flegrei areas, but they are lacking for the Ischia island. Since 1999, at least 78 earthquakes have been recorded on Ischia (updated to 21 
February 2018) (D’Auria et al., 2018), which have been localized using the model developed for the Campi Flegrei, on the basis of the similar geological and volcanological context of the two volcanoes. Taking into account the complex geological context of the island, aim of this work is to provide information on both shear wave velocity structure and effective attenuation in the uppermost $2 \mathrm{~km}$ depth. This objective is achieved using recordings of seismic noise at the seismic network present on the island as a large array (minimum interstation distance of about $1000 \mathrm{~m}$ ), since we expect that the minimum wavelength limit is higher than the estimated lithological heterogeneity thickness.

\section{Ischia island: structural and volcanic features}

The island of Ischia is the emerged portion of a large active volcanic complex, i.e. the Phlegraean Volcanic District, which also includes the island of Procida and the Campi Flegrei caldera (Orsi et al., 2003 and references therein) (see inset in Figure 1). Ischia is composed of volcanic rocks, epiclastic deposits and subordinate terrigenous sediments, reflecting a complex history of alternating constructive and destructive phases. The volcanic history of the island has been dominated by the large caldera-forming Mt. Epomeo Green Tuff eruption (Brown et al., 2008) occurred ca. 55 ka (Vezzoli, 1988). The caldera depression was the site of marine sedimentation, with generation of a sequence of tuffite, sandstone and siltstone (Figure 1).

The main morphostructural feature is the Mt. Epomeo resurgent block, delimited by two main trending fault systems (Acocella and Funiciello, 1999), which has an asymmetrical profile with the northwestern flank considerably steeper than the southeastern one as a result of an asymmetrical uplift. Outside the resurgent block, mainly in the eastern sector of the island (Figure 1), a lot of eruptive vents, probably injected during the resurgence process, are visible (Acocella et al., 2001). The surface expression of the volcano-tectonic features includes the north-northwest and southwest-facing steep flanks of Mt. Epomeo that are the gravitationally least stable slopes of the island. Mass movement deposits, likely generated by rock falls, slides, toppling, debris flows and debris avalanches (de Vita et al., 2006), are widespread on the whole island. The cause of the resurgence of Mt. Epomeo commonly accepted in the literature is the intrusion of magma into the system with a consequent raising of the caldera central part (Rittmann,1930; Rittmann and Gottini, 1980; Orsi and Chiesa, 1988; Orsi et al., 1991; Luongo et al., 1995; Tibaldi and Vezzoli, 1998; Molin et al., 2003; Carlino et al., 2006).

The main information on the buried structural setting of Ischia come from the numerous geophysical studies performed on the island. Capuano et al. (2015), using seismic and gravimetric data, have identified the presence of a high velocity and density area inside the caldera that well agree with the results of magnetic and self-potential surveys (Paoletti et al., 2009; 2013), which highlighted a minimum of magnetization in the central-western part of the island, suggesting the presence of a large intrusion, with the top ranging from 1.2 to $1.7 \mathrm{~km}$ b.s.l., overlaid by a pyroclastic cover. Shape and dimension of this structure fit well with the laccolith model with an E-W elongation proposed by Carlino (2012). In particular, the retrieved magnetization values suggest that this structure is formed by igneous rocks, very likely trachytes, according to the findings of core drilling (Nunziata and Rapolla, 1987). A further confirmation to the hypothesized laccolith emplacement comes from a recent magnetotelluric survey by Di Giuseppe et al. (2017) performed along two main profiles through the central-western sector of the island. The authors, by interpreting the obtained electrical sections up to $3 \mathrm{~km}$ depth, identify the presence of a very shallow magmatic intrusion at about $1 \mathrm{~km}$ depth, composed of crystalline rocks, which is probably connected to both resurgent and volcanic activity. 


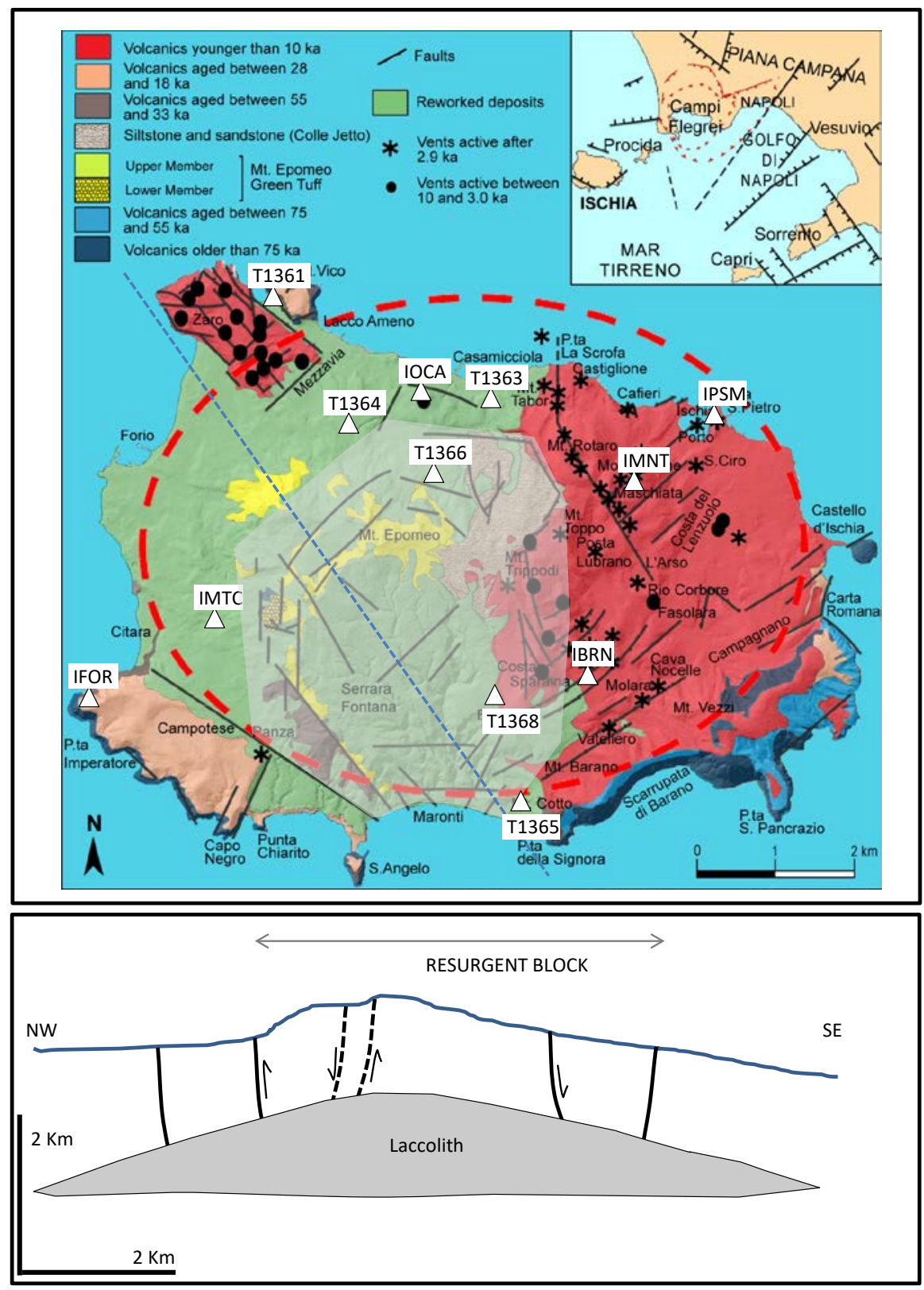

Figure 1: Geological map of Ischia Island. The red dashed line indicates the Mt. Epomeo Green Tuff Caldera (modified after de Vita et al., 2010). The white triangles indicate the location of seismic stations. The shaded grey polygon identifies the resurgence area and the blue dashed line is the trace of the simplified structural section shown below.

\section{Dataset and analysis}

After the $\mathrm{M}_{\mathrm{w}} 3.9$ earthquake, that hit Casamicciola town on August 21, 2017,the permanent monitoring network of the Ischia island was improved with other seismic permanent stations (IPSM, IMNT and IBRN in Figure 1 and Table 1, Orazi et al., 2018) and seven seismic stations of the mobile network (T136* in Figure 1 and Table 1, Galluzzo et al., 2019).

All the network stations, equipped with broad-band seismometers, accelerometers and short period sensors, transmit the seismic signals in real-time for seismic surveillance purposes. The dataset used in this study consists of seismic noise records registered at 12 broad-band stations (Table 1) during the period June-November 2018. 


\begin{tabular}{|c|c|c|c|c|c|c|c|}
\hline \multirow{2}{*}{$\begin{array}{l}\text { Station } \\
\text { Name }\end{array}$} & \multicolumn{3}{|c|}{ Coordinates } & \multirow{2}{*}{$\begin{array}{l}\text { Station } \\
\text { Name }\end{array}$} & \multicolumn{3}{|c|}{ Coordinates } \\
\hline & Latitude & Longitude & Elevation (m) & & Latitude & Longitude & Elevation (m) \\
\hline IOCA & 40.7468 & 13.9014 & 123 & T1361 & 40.7567 & 13.8789 & 7 \\
\hline IFOR & 40.7115 & 13.8551 & 234 & T1363 & 40.7455 & 13.9135 & 50 \\
\hline IMTC & 40.7209 & 13.8758 & 209 & T1364 & 40.7426 & 13.8905 & 129 \\
\hline IPSM & 40.7462 & 13.9439 & 10 & T1365 & 40.7014 & 13.9181 & 130 \\
\hline IMNT & 40.7361 & 13.9346 & 180 & T1366 & 40.7373 & 13.9046 & 213 \\
\hline IBRN & 40.7140 & 13.9268 & 150 & T1368 & 40.71089 & 13.91612 & 314 \\
\hline
\end{tabular}

Table 1: Geographic positions of the permanent and mobile seismic stations installed on Ischia and used for the present analysis (see Figure 1).
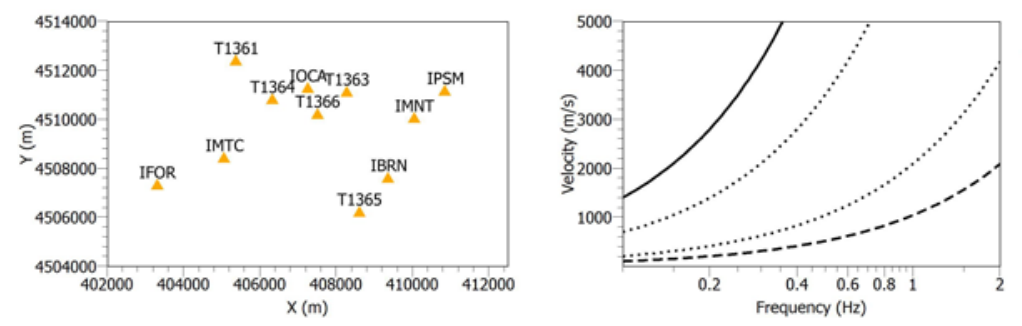

YELLOW CONFIGURATION

kmin: $0.000895216 \mathrm{rad} / \mathrm{m}$

kmax: $0.00601313 \mathrm{rad} / \mathrm{m}$

ground level. 0.0018543 a

kaverage: $0.00345417 \mathrm{rad} / \mathrm{m}$
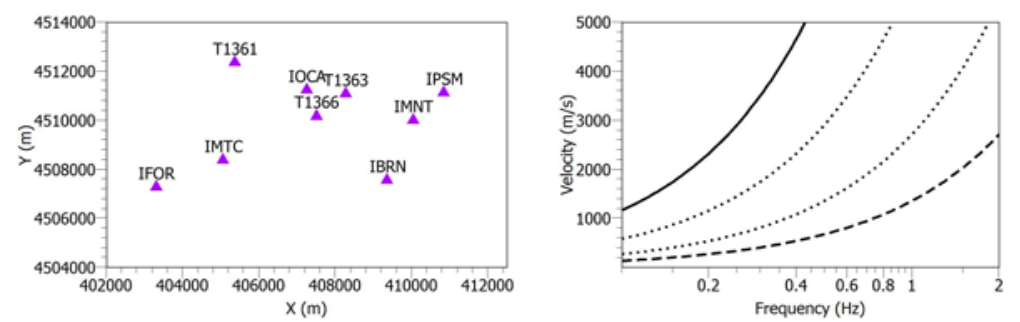

VIOLET CONFIGURATION

$\mathrm{kmin}: 0.00107955 \mathrm{rad} / \mathrm{m}$

kmax: $0.00463573 \mathrm{rad} / \mathrm{m}$

kmax-kmin: $0.00355618 \mathrm{rad} / \mathrm{m}$

kaverage: $0.00285764 \mathrm{rad} / \mathrm{m}$
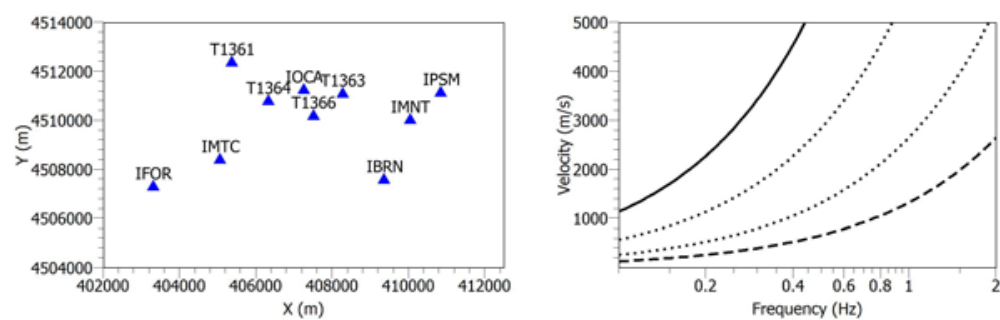

BLUE CONFIGURATION

kmin: $0.00110334 \mathrm{rad} / \mathrm{m}$

kmax: $0.00474331 \mathrm{rad} / \mathrm{m}$

ground level: $0.0850004 \mathrm{rad}$

$\mathrm{kmax}-\mathrm{kmin}: 0.00363997 \mathrm{rad} / \mathrm{m}$
kaverage: $0.00292332 \mathrm{rad} / \mathrm{m}$
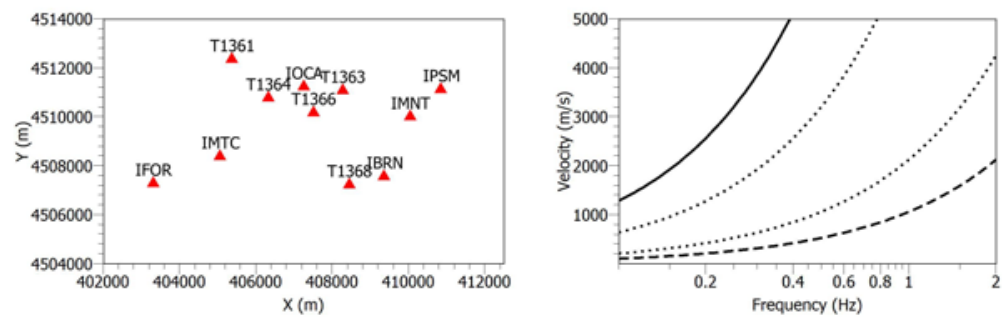

RED CONFIGURATION

kmin: $0.000977988 \mathrm{rad} / \mathrm{m}$

kmax: $0.00591165 \mathrm{rad} / \mathrm{m}$

ground level: 0.0817906

kmax-kmin: $0.00493366 \mathrm{rad} / \mathrm{m}$

kaverage: $0.00344482 \mathrm{rad} / \mathrm{m}$

Figure 2: Left side: geometry of the array. The coordinates are in the UTM system.Right side: the four exponential curves represent constant wavenumber values: $\mathrm{kmin} / 2$ (continuous line), $\mathrm{kmin}$ (dot line), kmax/2 (dots line) and kmax (dashed line).

Stations did not acquire the data simultaneously, and the $75 \%$ of the stations recorded constantly for more than 20 hours. Due to the non-continuity of registration of some sites, it was necessary to divide the dataset into four sub-array configurations (named yellow, violet, blue and red, respectively, Figure 2), and for each one the theoretical array limits (the 
minimum wavenumber "kmin” and the maximum wavenumber "kmax"), as specified by Wathelet et al. (2008), were calculated (Figure 2).

The resolution limits for all the configurations are quite similar and the yellow one has the minimum and the maximum values of both kmin and kmax. As a final point, our array limits, overlying on the yellow configuration the ranges of the subsoil layer velocity obtained by Strollo et al. (2015) and Vassallo et al (2018),are to be expected in the $0.15-1.2 \mathrm{~Hz}$ frequency range (following the formulation $v=(2 \pi * f / k)$ ).

\section{$\underline{\text { Array analysis }}$}

In order to obtain the phase velocity of the surface waves, and consequently the subsoil velocity structure, we used the SPAC method (Aki, 1957) applied to the recordings of noise. This method allows us to obtain the dispersion curve of surface waves estimating the correlation function between pairs of stations, with different azimuths, in different frequency bands. Assuming that the wave field is stochastic and stationary both in time and space, and that it is dominated by surface waves as well, the method provides a relationship between spatial and temporal spectrum of the ground motion. Aki (1957) showed that the relationship between the average of different correlation functions and the autocorrelation function, calculated for each pair of vertical signals, which he defined "correlation coefficient”, $\rho$, has the shape of a Bessel function of zero or first order. The method states that the azimuthal average of the correlation coefficients $\rho(r, \omega)$ calculated for pairs of vertical components of the signal can be expressed as a function of the angular frequency $\omega$ and of the station spacing $r$ as:

$$
\rho(r, \omega)=J_{0}\left[\frac{r \omega}{c(\omega)}\right]
$$

where $\mathrm{J}_{0}$ represents the Bessel function of zero order and $\mathrm{c}(\omega)$ is the Rayleigh wave phase velocity dispersion function.

Since seismic waves will always lose energy during their travel, Prieto et al. (2009) showed that equation (1), in order to take into account attenuation for plane waves, can be modified as

$$
\begin{aligned}
& \rho(r, \omega)=J_{0}\left[\frac{r \omega}{c(\omega)}\right]^{[-\alpha(\omega) r]} \\
& a(\omega)=\omega 2 Q_{r}(\omega) c(\omega),
\end{aligned}
$$

where $\alpha(\omega)$ represents the frequency-dependent Rayleigh wave attenuation factor and $Q_{r}(\omega)$ is the frequency-dependent quality factor for Rayleigh waves. The phase velocity $\mathrm{c}(\omega)$ can be obtained at different frequencies computing the average correlation coefficient for couples of signals filtered in narrow frequency bands at fixed distances. Bettig et al. (2001) brought some slight modifications to the original formula given by equation (1) to extend the method to irregular arrays. Since our array has a non-conventional geometry, we applied the processing proposed by Betting et al., defined as MSPAC method (Bettig et al., 2001), to analyse the seismic noise signals. Once the phase velocity and $\alpha(\omega)$ are known, $Q_{r}(\omega)$ can be estimated using equation (3).

We divided each of the four arrays in semi-circular sub arrays called "Rings", whose radii are defined by the sensor's spacing, and we calculated the spatial autocorrelation for all the possible pairs of sensors (Bettig et al., 2001; Wathelet et al., 2004, 2005, 2008). Each Ring is the result of an appropriate balance between the number of sensor pairs per Ring (as large as possible) and the thickness of the Ring (as small as possible). Thus, our geometry is composed by 6 Rings (the sub-array of the yellow configuration is displayed in Figure 3), ranging from a minimum of about $1000 \mathrm{~m}$ to a maximum of about $8500 \mathrm{~m}$ spacing of the sensors, for a total of maximum 55 sensor pairs. Having fixed time windows and frequency band, the MSPAC method calculates the autocorrelation between the station pairs and averages over the azimuthal directions. 


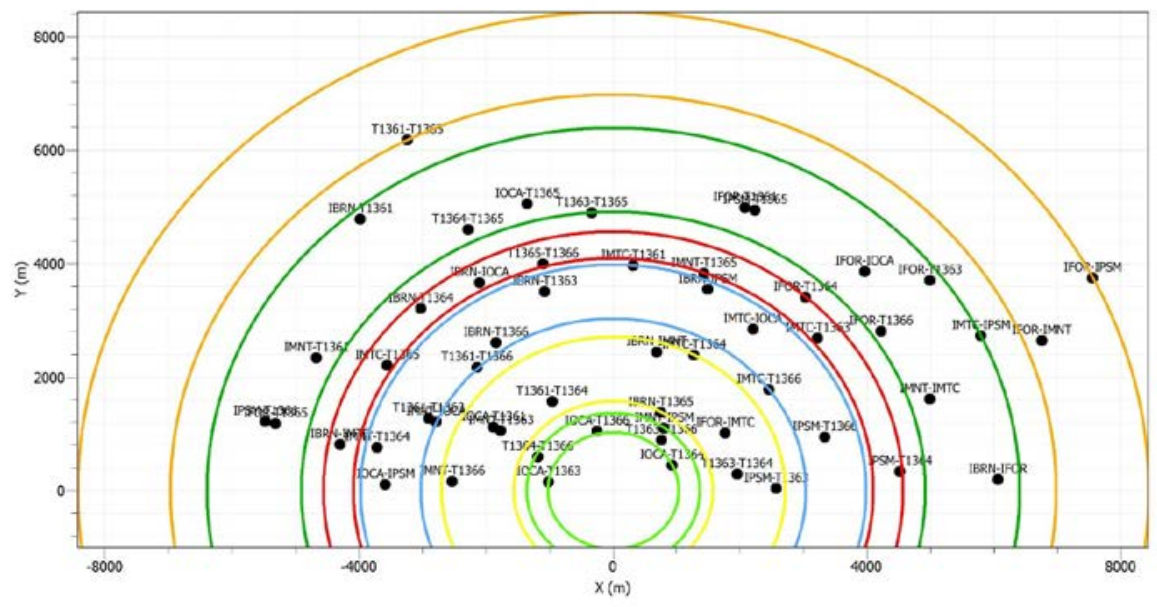

Figure 3: Azimuth-inter-distance plot for the yellow configuration. Each dot represents one couple of stations. The pairs of colour circles show the limits of the chosen rings. In the table are reported the coloured distance intervals of each Ring.

The time windows are set to a period of $\mathrm{T}=500 \mathrm{~s}$, with a $25 \%$ overlap, for each frequency in the range $0.1-1.5 \mathrm{~Hz}$, using 100 logarithmically spaced frequency values.

The correlation coefficients of the 6 Rings calculated for each sub-array configuration were averaged (Figure 4a-f) and, according to equation (1), we derived the Rayleigh wave phase velocity values (grey dots in Figure 4g) by the reading of zero crossings, maxima and minima of the correlation functions (Aki, 1957). The dispersion values show high variability mostly at frequency below $0.6 \mathrm{~Hz}$. As suggested by Foti in 2000, since the number of points in a complex dispersion curve is not manageable for the successive inversion process, it is necessary to reduce it by an averaging, smoothing and resampling operation. Thus, due to the scatter of the velocity values we decided to interpolate the dispersion values by a polynomial fitting (continuous red curve in Figure 4g) and picked the maximum and minimum dispersion values (dotted red curves in Figure 4g). Finally, the dispersion curve to invert (black crosses with the relative standard deviation) was obtained by an averaging, smoothing and resampling process on the grey dots and the three red picked curves (see Figure 4g). The velocity values, as a function of frequency, show a distinctive dispersive behaviour that can be associated with the presence of surface waves in the signal (Arai and Tokimatsu, 2005). 

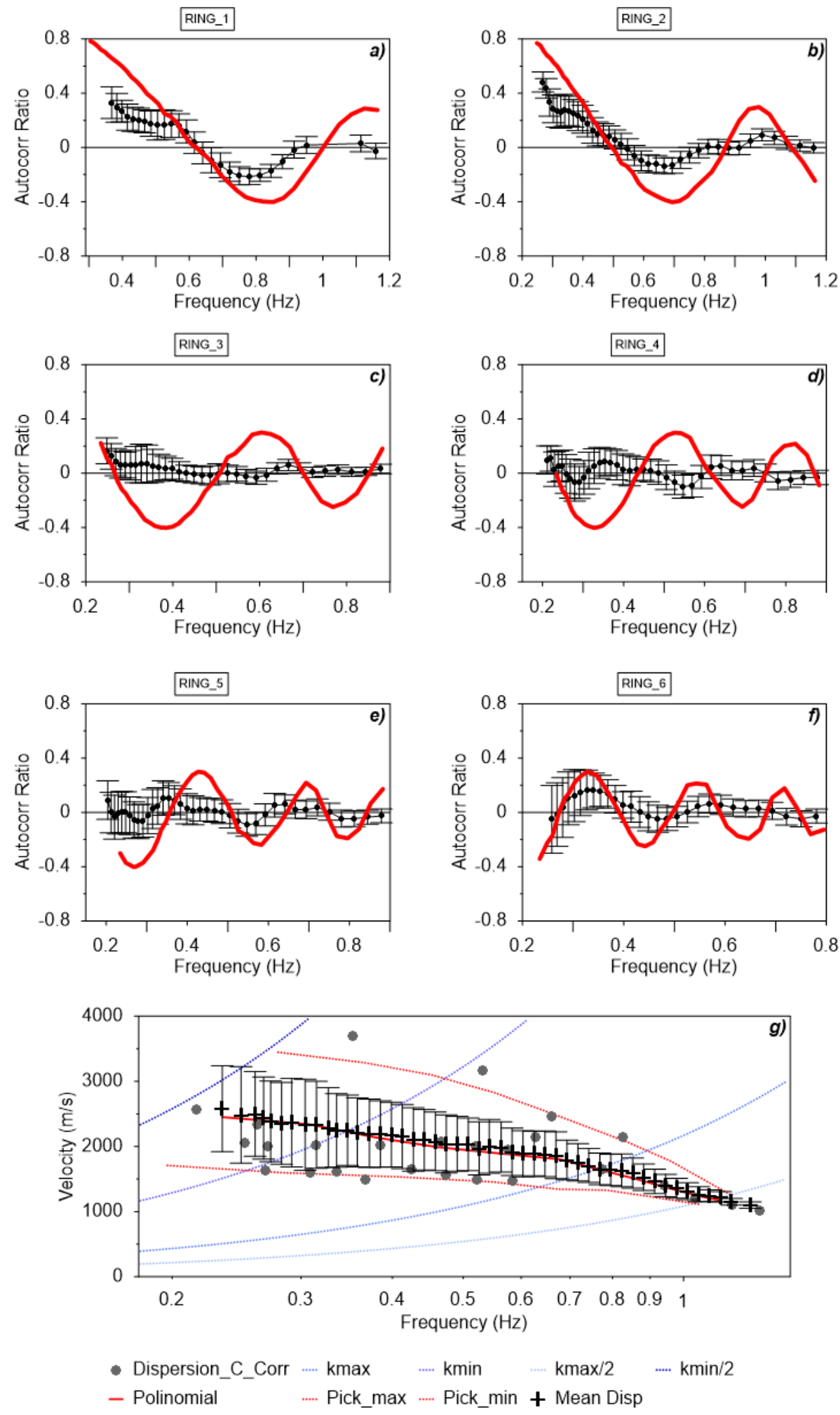

Figure 4: a-f: Mean correlation coefficients as function of frequency obtained averaging the correlograms of the four configurations. Error bars indicate the standard deviation. The red curve represents the zero-th order Bessel function. g: phase velocity values (grey dots) derived from the six averaged correlograms. The black crosses with the relative error bars are obtained by averaging, smoothing and resampling the grey dots and the three red picked curves. The four dotted shades of blue curve are from kmin=2 (the dark one) to kmax (the light one), which are described in Figure 2. 


\section{Spectral Analysis}

In order to check the isotropy of noise sources around the Ischia island we have applied the $f-k$ method (Lacoss et al., 1969; Capon, 1969) to our dataset, because this method provides a representation of the distribution of the seismic energy. This is necessary because in a volcanic environment, such as Ischia island, in some place it is possible deviate from the isotropic source assumptions (Nakanara, 2012). Thus, we band pass filtered the signals in the $0.1-2 \mathrm{~Hz}$, choosing 100 logarithmically spaced center frequency $\left(f_{c}\right)$. We selected the time-window length as being 500 times the central period $\left(1 / f_{c}\right)$ with a $25 \%$ overlap between successive windows. For each $f_{c}$, the $f-k$ spectrum was computed over a grid and the back-azimuth values were selected from the maxima of the spectrum at the corresponding frequency. The distribution of back-azimuth values computed for each time window is scattered (Figure 5a and Figure 5b), lacking any dominant direction of propagation. There is an isotropic, or weakly heterogeneous, wave field distributed in the $0^{\circ}-360^{\circ}$ degree, reproducing the time-spatial stationary of the signal in the analyzed frequency range.

For Ischia island the seismic energy and the back-azimuth of the sources reflect the action of the ocean waves and atmospheric turbulences which are more or less isotropically distributed all around, generating probably the fluctuation of the hydrostatic pressure caused by surface waves (generally at frequency $>0.3 \mathrm{~Hz}$ ) in a shallow sea (Obermann and Hillers, 2019 and references therein). These sources are almost all around the island except the western sector, where the lowest number is related to the lack of seismic sources in the $0.1-0.3 \mathrm{~Hz}$ frequency band. This effect is highlighted in the distribution of the back-azimuth as a function of the frequency (Figure 5b). Such variability not affects our results since it is outside of our frequency range derived from the experimental dispersion curve (Table 2).

Table 2: relation between minimum and maximum frequency, phase velocity and wavelength for the experimental dispersion curve reported in Figure 4g.

\begin{tabular}{|c|c|c|}
\hline $\begin{array}{c}\text { Frequency band } \\
\text { fmin }- \text { fmax }(\mathrm{Hz})\end{array}$ & $\begin{array}{c}\text { Phase velocity } \\
c(\omega)(\mathrm{m} / \mathrm{s})\end{array}$ & $\begin{array}{c}\text { Wave length } \\
\lambda(\mathrm{m})\end{array}$ \\
\hline $0,26-1,2$ & $1055-2525$ & $880-9500$ \\
\hline
\end{tabular}

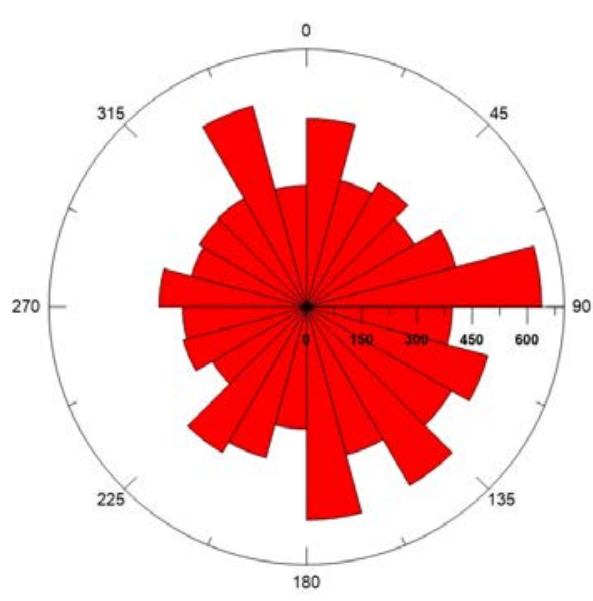

a)

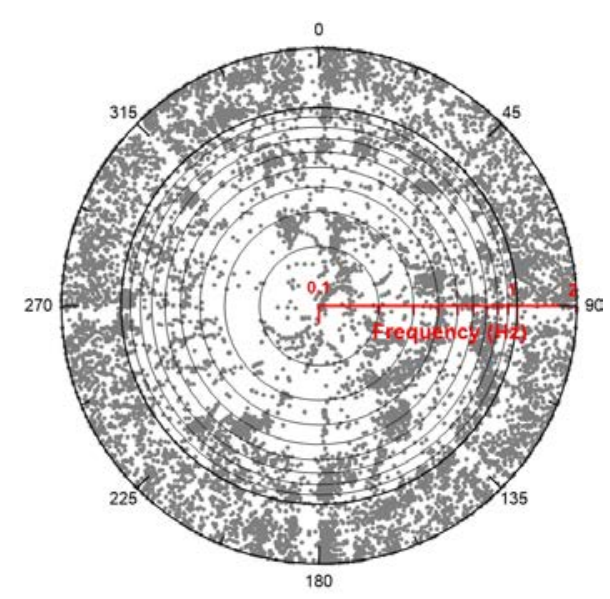

b)

Figure 5: distribution of propagation azimuths for 0,1 - 2,0 Hz. a) histogram distribution of propagation azimuth. Each bin amplitude for the histograms is $15^{\circ}$ wide. b) polar plot distribution of the back-azimuth as a function of the frequency. 
Taking into account the resolution limits of the geometry of the seismic stations (Figure 2 and Figure 4), we can see that the available frequency interval for the analysis ranges from $0.1 \mathrm{~Hz}$ to almost $1.2 \mathrm{~Hz}$. For this reason, we decided to compute the horizontal to vertical spectral ratios $(\mathrm{H} / \mathrm{V})$ in the $0.1-2 \mathrm{~Hz}$ frequency band. We used the GEOPSY package (Wathelet et al., 2004) selecting at least one hour of noise signals and calculating, on 120s moving time windows with 5\% overlap, the spectral ratios (Figure 6). The continuous black curves, with the relative error bars, represent the average H/V ratio obtained over one hour of noise, while the red curves, with the relative error bars, indicate the mean H/V ratio. The stationary results refer to the stability of the $\mathrm{H} / \mathrm{V}$ ratios throughout the analysis, which means that the $\mathrm{H} / \mathrm{V}$ ratios performed on a time-window should be as similar as possible each other, especially with respect to the amplitude peak frequency. In the case of a layered medium with a strong impedance contrast at depth, the peak frequency in the H/V curve is very close to the peak frequency of the ellipticity curve for the Rayleigh waves, and it interprets well the resonance frequency for the S-waves. In the case of moderate contrasts, the H/V curve does not show any clear resonance peak (Bonnefoy-Claudet et al., 2008).

All the analyzed stations show the presence of a peak in the $0.3 \mathrm{~Hz}-0.7 \mathrm{~Hz}$ frequency range. The stations placed near the north coast, such as T1361 and IPSM, exhibit the minimum frequency peaks, $0.36 \mathrm{~Hz}$ and $0.37 \mathrm{~Hz}$ respectively. Whilst the stations placed in the central and/or in the southern part of the island, such as IMTC, T1368, T1365 and T1366, show the highest frequency peaks $(0.6 \mathrm{~Hz}, 0.63 \mathrm{~Hz}, 0.59 \mathrm{~Hz}$ and $0.62 \mathrm{~Hz}$, respectively). A rising trend of the H/V curve at frequency lower than $0.2 \mathrm{~Hz}$ (particularly at station IBRN) is clearly visible at all stations. At frequency higher than $1.0 \mathrm{~Hz}$, the shape of the spectral ratios shows significant differences, which are most likely related to the different site conditions.
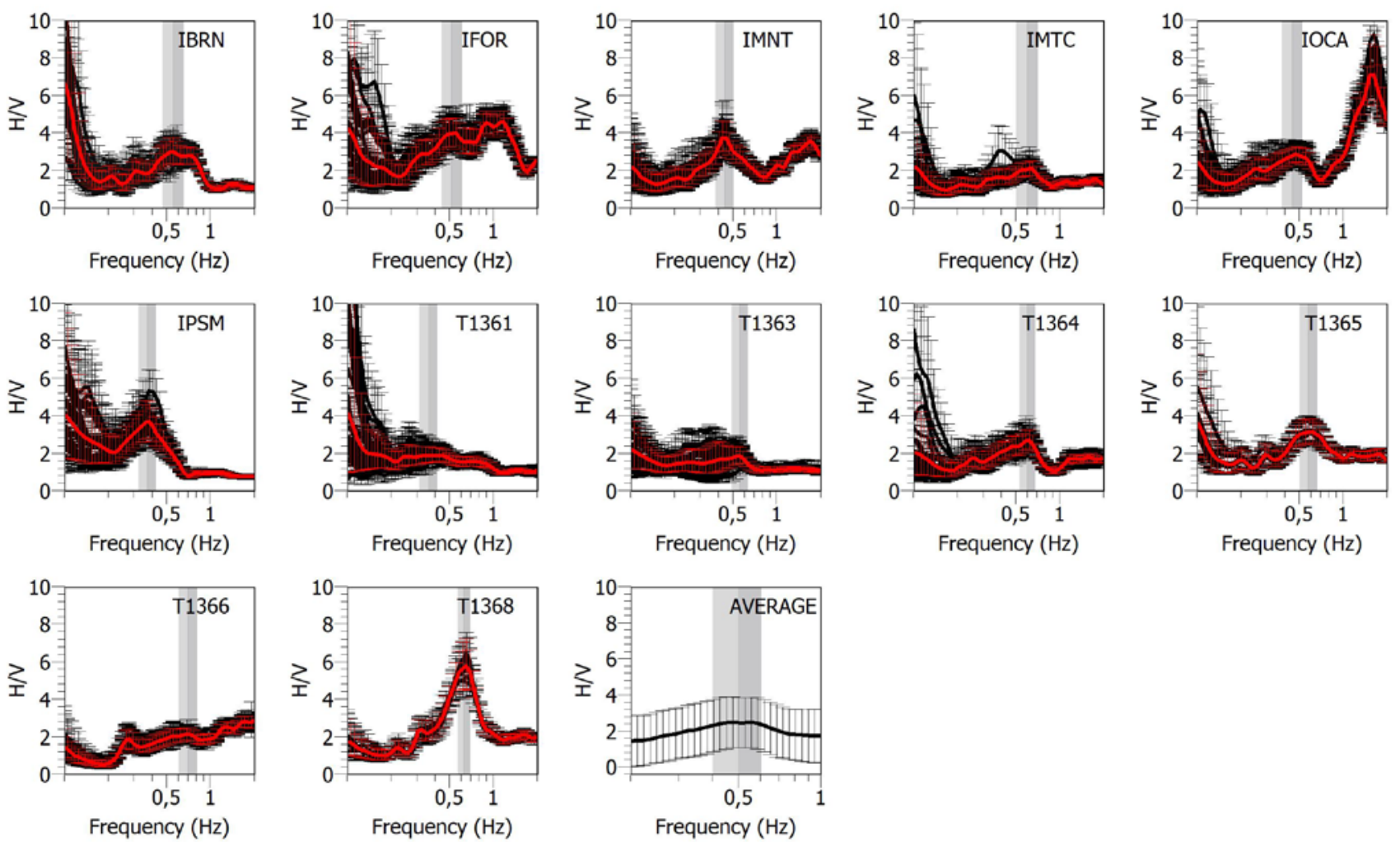

Figure 6: Noise $\mathrm{H} / \mathrm{V}$ ratios as a function of the frequency. The black curves, together with the error bars, represent the mean $\mathrm{H} / \mathrm{V}$ ratios calculated on one hour of signal. The grey vertical band indicates the maximum in the $\mathrm{H} / \mathrm{V}$ ratios, or rather the mean frequency peak, $\mathrm{f}_{0}$. The red curve is the mean on all the black ones. 
To obtain the mean $\mathrm{H} / \mathrm{V}$ ratio of all the stations in the same frequency band of the dispersion curve (Figure 3), and to study the amplitude peak in the $0.35-0.7 \mathrm{~Hz}$ frequency range, we made an average of both all $\mathrm{H} / \mathrm{V}$ ratios and frequency peaks (average in Figure 6) not including the high amplitude values at frequency lower than $0.2 \mathrm{~Hz}$ and the frequencies higher than $1.0 \mathrm{~Hz}$.

\section{Inversion procedure and results}

To invert the dispersion data, we made the basic assumptions that Rayleigh waves are predominant in the vertical plane and that the experimental $\mathrm{H} / \mathrm{V}$ curve can be interpreted as the ellipticity of the Rayleigh waves. Moreover, the frequency of the ellipticity peak contains pertinent information about the thickness and the S-wave velocity above the basement. If the ellipticity targets are added to a usual dispersion curve inversion, they can improve the final solution (Foti et al., 2017; Di Giulio et al., 2020 and reference therein). Therefore, to better constrain the inversion procedure of the dispersion curve in the $0.2-1.1 \mathrm{~Hz}$ frequency band, the average $\mathrm{H} / \mathrm{V}$ curve and the resonance frequency (whose value depends on the layer thickness and shear-wave velocity, Kramer, 1996) have been used. We have utilized the neighborhood algorithm "Dinver" employed by Wathelet et al. (2008), which infers the best velocity model through a stochastic search in a multi-parameter space. One point of this space corresponds to one velocity model defined by S- and P-wave velocities, thickness, densities and Poisson’s ratios of the soil layers, and synthetic dispersion and ellipticity curves are calculated by inverting the S-wave equation as function of the surface waves velocity. For all the performed inversions, we have kept fixed the density of the layers, using the values reported in Paoletti et al. (2013) and Capuano et al. (2015), and we have linked all the other parameters to Vs. This is reasonable as the Rayleigh wave velocities depend strongly on the $\mathrm{V}_{\mathrm{S}}$ structure and weakly on the density (Wathelet et al., 2005).

In a preliminary study, Galluzzo et al. (2018), using ambient noise records of 10 broad-band seismic stations installed on Ischia, obtained a preliminary model composed of two main layers over a half-space with as hear-wave velocity increasing with depth. Starting from the results found by Galluzzo et al. (2018), we performed 11 inversion processes. During the inversion procedure, the possibility of adding another layer has been explored by modifying the space of the parameters and considering the evolution of the misfit as a function of $\mathrm{V}_{\mathrm{S}}$ and thicknesses. We have chosen to modify only these two parameters as they have the greatest influence on the dispersion curve (Wathelet et al., 2005). The models resulting from the inversion process show a good fit (minimum misfit $=0.15$ ) between experimental and theoretical curves by using a model parameterization composed of three main layers over a half-space with a shear-wave velocity increasing with depth (Figure 7 and Table 2).

The evolution of the misfit value as a function of the number of models of the best seven inversion runs is shown in Figure 8(top panel). For each independent run, there was convergence to stable best-fit solutions after about 12,000 generated models, that is when misfit is lower than 0.3. The lowest misfit corresponding to the best-fit solution is equal to 0.15 (Figure 8) and is related to RUN7. To appreciate the robustness of this solution, we also projected the misfit function as a function of Vs and h (Figure 8 bottom). Each model generated is represented by a dot with a color scale that depends on the misfit value. The shape of the convergence of the inversion gives valuable information about the uncertainty of the solution. We observe good convergence towards the best-fit solution of both of these parameters. 

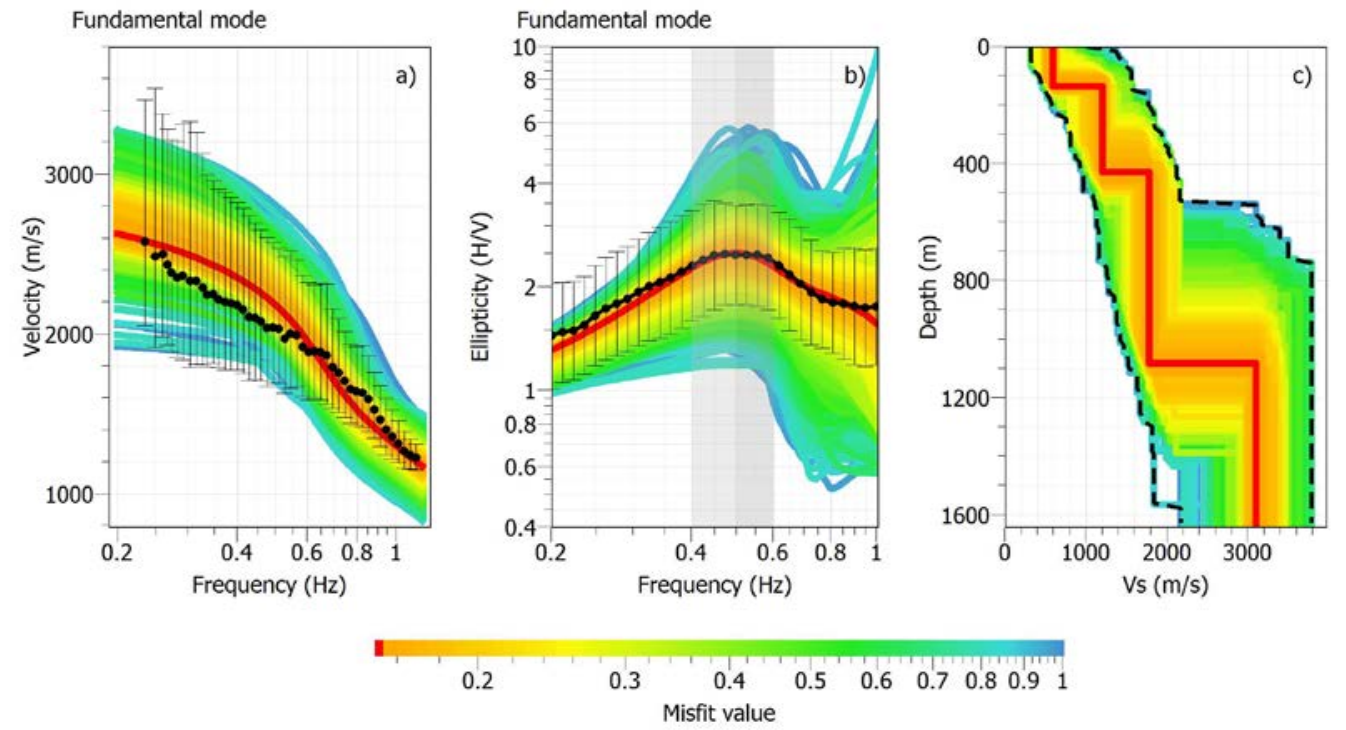

Figure 7: Results of the joint inversion of dispersion and $\mathrm{H} / \mathrm{V}$ data. a) Observed phase velocities (black dots) and relative error bars, phase velocities for the minimum cost model (red line), and phase velocities for the space of stable generated models (color band). b) Mean H/V (black dots) and relative error bars, ellipticity function for the fundamental mode of Rayleigh waves for the minimum cost model (red line), and ellipticity functions for the space of stable generated models (color band). The grey vertical band identifies the mean frequency peak, $f_{0}$. c) Minimum misfit S-wave velocity model (red line) and space of stable generated models (color band).
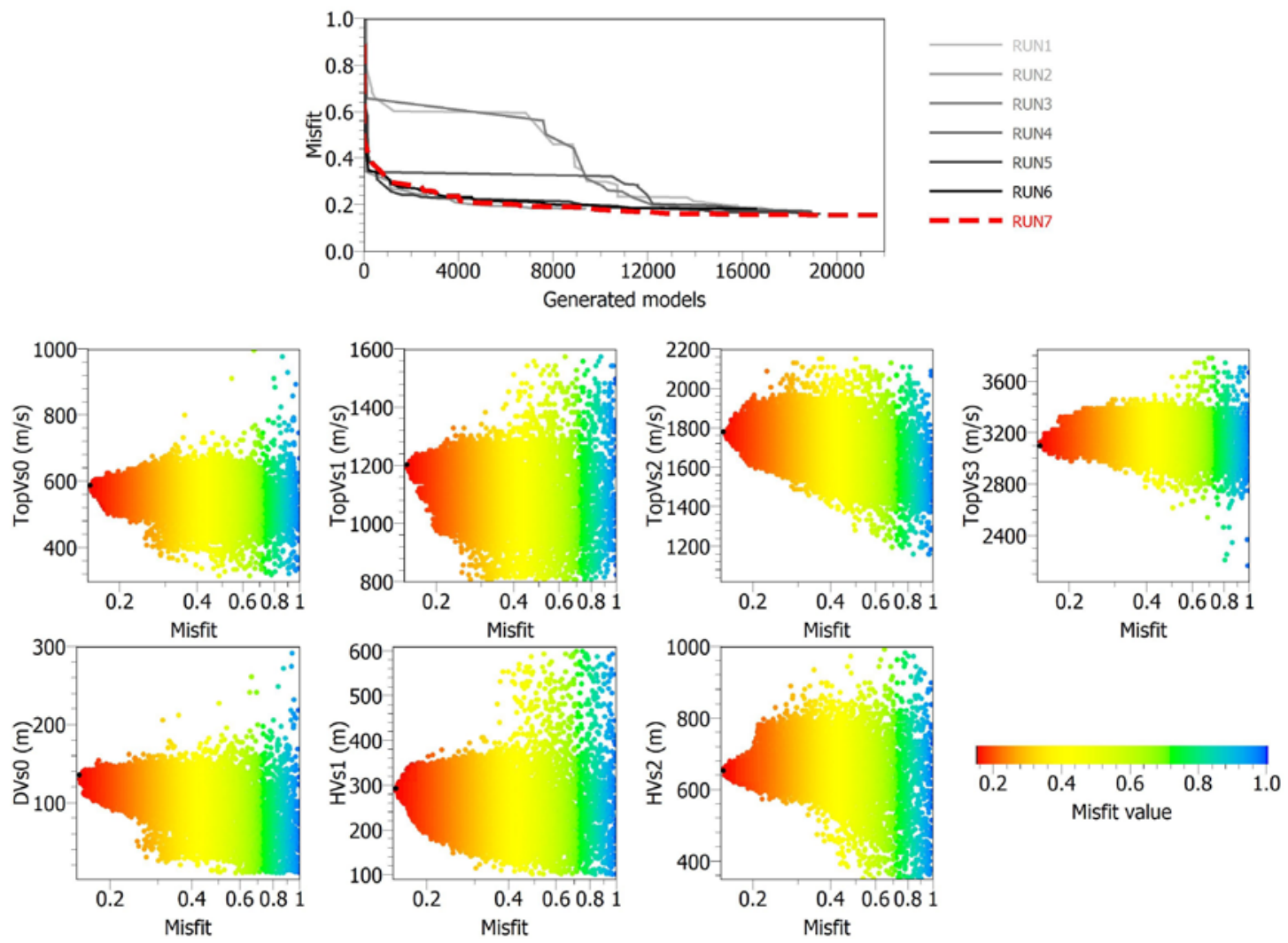

Figure 8:Top: Evolution of the misfit value as a function of the generated models. Data from seven independent runs are plotted. Bottom: Projection of all the generated models with minimum misfit lower than 1 (dots), as a function of the misfit and one of the inverted parameters. TopVs0 and DVs0 denote Vs and thickness of the first layer, respectively; TopVs1 and HVs1 denote Vs and 
thickness of the second layer, respectively; TopVs2 and HVs2 denote Vs and thickness of the third layer, respectively, and TopVs3 denotes Vs of the half space. The black dot is the best fit solution.

\begin{tabular}{|c|c|c|c|}
\hline Layer & $\begin{array}{c}\text { Vs } \\
(\mathbf{m} / \mathbf{s})\end{array}$ & $\begin{array}{c}\text { Thickness } \\
(\mathbf{m})\end{array}$ & $\begin{array}{c}\text { Density } \\
\left(\mathbf{K g} / \mathbf{m}^{\mathbf{3}}\right)\end{array}$ \\
\hline 1 & 588 & 135 & 2000 \\
\hline 2 & 1203 & 293 & 2200 \\
\hline 3 & 1780 & 654 & 2400 \\
\hline Hs & 3098 & - & 2600 \\
\hline
\end{tabular}

Table 3: Best-fit Vs model derived from the joint inversion. Hs=Half space.

\section{Discussion and conclusion}

By means of correlation analysis and spectral ratios, and synthesizing this information into a 1D joint inversion, we were able to determine the mean structure of velocity and attenuation of Ischia volcanic island. In a such geological contest, we were aware of the existence of local lithological heterogeneities that, in principle, advise against the use of the array correlation method and could affect the analysis. At Ischia, the major seismic velocity and/or structural differences are smaller than the minimum wavelength resolution of the available arrays, an important assumption for the effective medium theory. In case of a heterogeneous distribution of attenuation, the SPAC method can reduce the effect by taking the average over many pairs of stations with similar separations but different azimuth angles (Nakahara, 2012). This statement is valid if noise sources are distributed so as to balance exactly with the heterogeneous attenuation. Thus, we checked the noise sources distributed homogeneously and randomly (see Figure 5).

We verified from previous studies (Strollo et al., 2015; Vassallo et al., 2018) that inhomogeneities are mostly confined in the first few hundred meters' depth and, thus, it is possible to assume that the island of Ischia, on a large scale, can be approximated as a medium with 1D geometry. In order to better clarify this assumption and due to the unavailability of specific figures in the EGU abstract of Vassallo et al. (2018), we have reported below the 3D geological representation of Ischia (Geological Map of Ischia Island, CARG Scale 1:10.000, from Sbrana et al. 2011, N 464). The map confirms that the major lithological variations are in the first $200 \mathrm{~m}$ depth and are related to the shallower gravitationally mass movement deposits, which are widespread on the whole island (de Vita et al., 2006), or to local volcanological deposits such as lava domes or lava flows of active vents (de Vita et al., 2010). The geometry and the morphology of the principal layers are dominated by the faults, dislocating the surfaces along sub-vertical planes. These structural variations, that connect two different lithologies, localized in a restricted area around the fault, are not recognizable when we consider wavelength of about $400 \mathrm{~m}$. In these cases, we can assume a smoothed geometry of the layers (concerning the variation of the layers' thicknesses) that can be approximated to a $1 \mathrm{D}$ structure. 


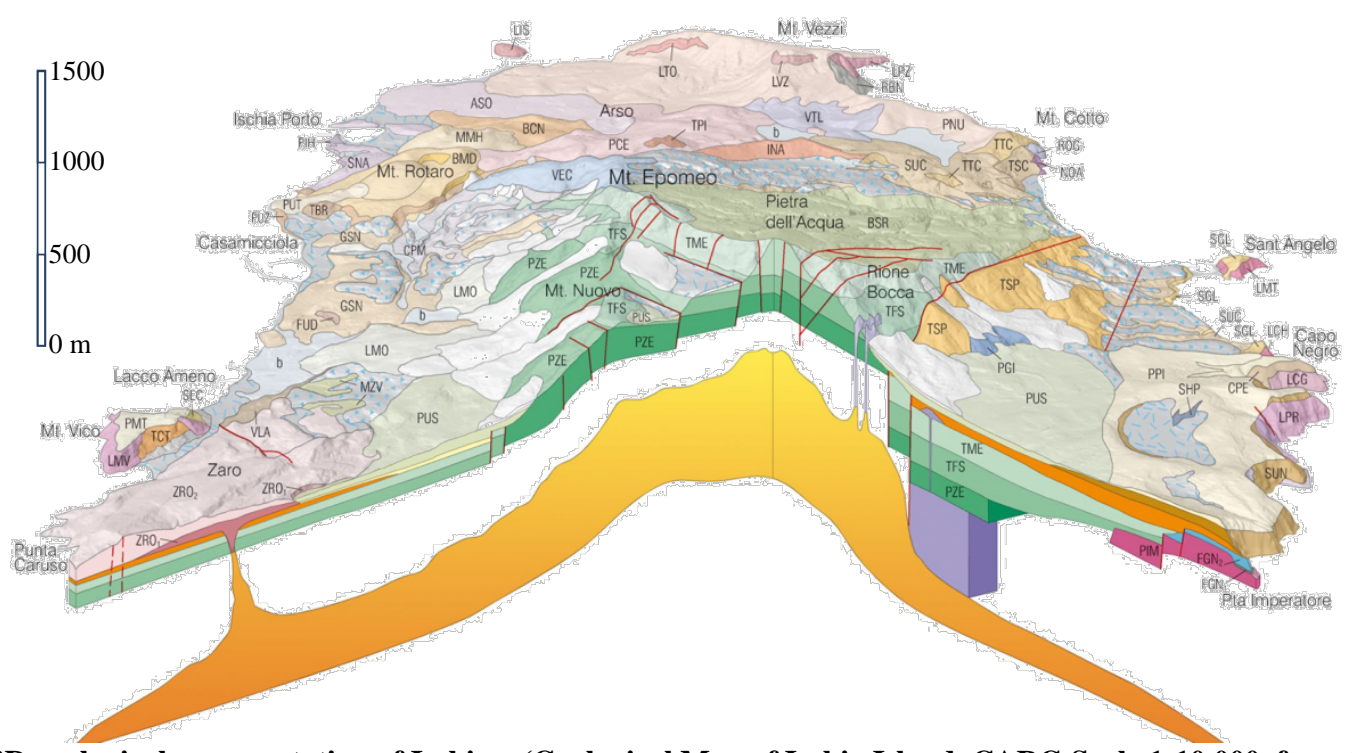

Figure 9: 3D geological representation of Ischia - (Geological Map of Ischia Island, CARG Scale 1:10.000, from Sbrana and Toccaceli, 2011, $\mathbf{N}^{\circ}$ 464). For specific description of lithologies refer to Sbrana and Toccaceli, 2011.

Taking into account the involved frequencies range, these observations allowed us to consider the obtained velocity model as representative of the whole island. The same assumption has permitted to obtain the Q attenuation model, where Q does not differentiate scattering from intrinsic attenuation properties (Boxberger et al., 2017). As suggested by Spica et al. (2015), despite the presence of lateral heterogeneities, the 1D velocity profile carries information about the average properties of the crust and can be considered as a good approximation of the velocity structure (e.g., Dziewonski and Hales, 1972; Ekström et al., 1997).

Comparing the values retrieved for the S-wave velocities with the known stratigraphic data from deep boreholes, drilled up to a depth of 1150 m (Penta and Conforto, 1951; Penta, 1963; AGIP, 1987), we have provided a geological interpretation of the resulting velocity model (Figure 10 left). The first seismic layer is interpreted as composed mainly of remobilized deposits of the Green Tuff, volcanic rocks, epiclastic deposits and subordinate terrigenous sediments, reflecting a complex history of the surface morphological evolution, and also of altered portion of the marine post-calderic filling sequence of tuffite, sandstone and siltstone. The second seismic layer has been associated to the Mt. Epomeo Green tuff and to the lithified calderic filling sequence of tuffite, sandstone and siltstone. The velocities obtained for these two shallower layers are comparable with those obtained by Strollo et al. (2015) and by Vassallo et al. (2018) on Ischia island, and are coherent with those found for both loose and lithified facies of the Neapolitan tuffs (Petrosino et al., 2012; Maresca et al. 2014; Costanzo and Nunziata, 2019). The third seismic layer (from $\sim 400 \mathrm{~m}$ to $\sim 1100 \mathrm{~m}$ depth) is interpreted as composed predominantly of trachytic lava, with partial hydrothermal alteration, and marginally of old pyroclastic rocks (older than 75 Kyr, Vezzoli, 1988). Di Napoli et al. (2011)have demonstrated that a hot fluid circulation, with temperature from $\sim 150^{\circ}$ to $\sim 270^{\circ} \mathrm{C}$, occurs in at least 2 distinct superimposed reservoirs located at depths ranging from $200 \mathrm{~m}$ to1000 $\mathrm{m}$ b.s.l.. The complex hydrothermal system that characterizes the Ischia island, consisting of different superimposed reservoirs, is recharged by meteoric and seawater in various proportions, where heat and mass budgets are probably sustained by degassing of a magmatic body at depth (Chiodini et al., 2004; Di Napoli et al., 2009). We are not able to distinguish in the Vs profile these two layers or the most fractured areas through which the hot hydrothermal fluids move, probably because are limited to the fracture zones (Di 
Napoli et al., 2011). The last seismic layer, corresponding to the half space, is interpreted as composed of the laccolithic crystalline rocks $\left(\mathrm{V}_{\mathrm{S}} \sim 3100 \mathrm{~m} / \mathrm{s}\right)$. This hypothesis is supported by velocity values measured in laboratory on samples of lava and granite. If no other evidences are available, laboratory experiments can provide complementary information on the physical properties of volcanic materials and their behaviour as a function of several parameters, including pressure and temperature (Lesage et al., 2017). In 2002,Vanorio et al. measured the acoustics properties of trachytic lava samples from Mt. Etna (Sicily, southern Italy) under confining pressure (up to $60 \mathrm{MPa}$ ) and found average wave velocities $\mathrm{V}_{\mathrm{S}}$ equal to $\sim 3000 \mathrm{~m} / \mathrm{s}$ for a confining pressure of $20 \mathrm{MPa}$ (pressure estimated for a depth of about $1100 \mathrm{~m}$ corresponding to the crystalline laccolith top).

The shallow top of the laccolith (1-2 km depth) was inferred using different constrains, such as geological, geochemical, seismic, magnetic, gravimetric and self-potential data (Paoletti et al., 2009; Sbrana et al., 2009; Carlino,2012; Capuano et al., 2015, Strollo et al., 2015). Due to the high temperature of about $800^{\circ} \mathrm{C}$ (Carlino et al., 2014), this laccolith is considered responsible for rising of deepCO $\mathrm{CO}_{2}$-rich gases, which dissolve into the overlaying aquifer systems, giving rise to the robust geothermal system of the island. Using the temperature-depth curves measured in deep wells, down to about $1 \mathrm{~km}$ depth, Carlino et al. (2014) have deduced the layer of a well-developed geothermal system. For greater depths, they extrapolated the geotherm as a mean value of the deeper linear part of measured temperatures, and found the brittle ductile transition zone at about $2 \mathrm{~km}$ of depth (orange forward slash band in Figure 10).

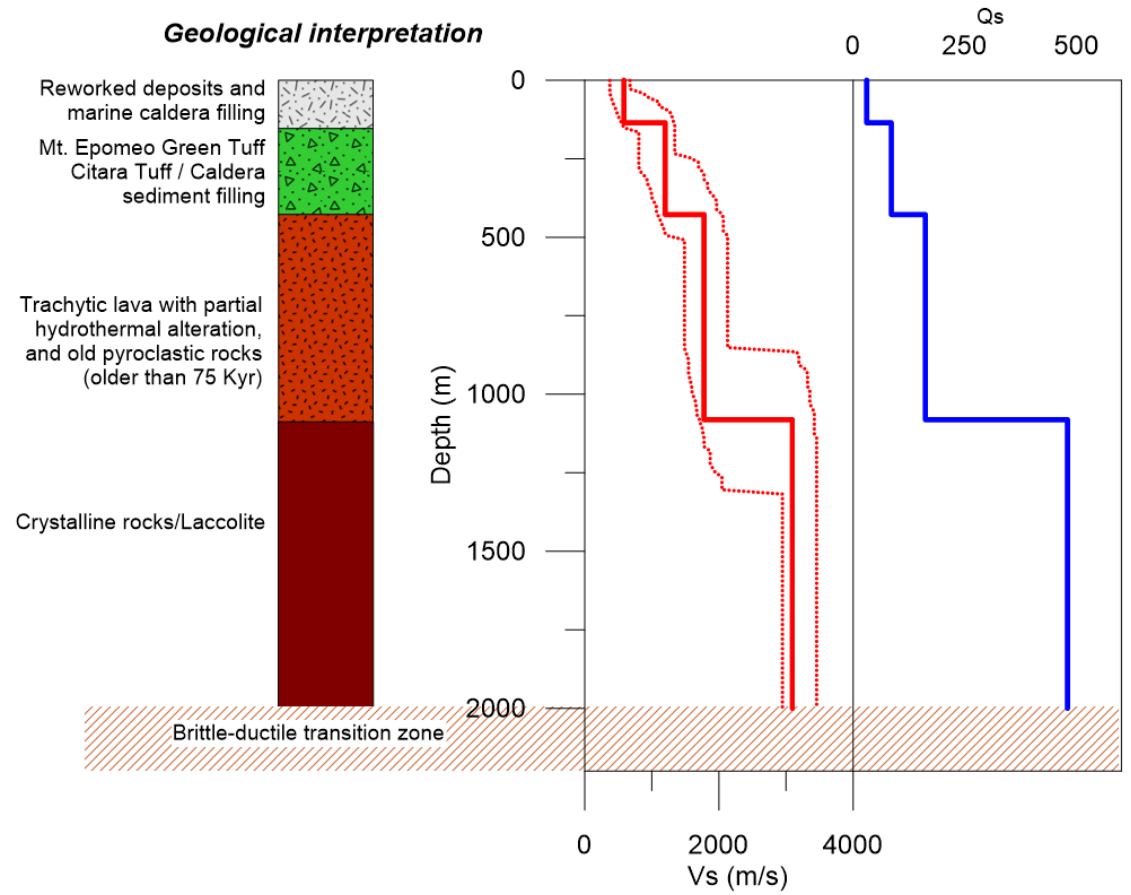

Figure 10: Left: Schematic lithological sequence. Right: Vs plus/minus standard deviation (red) and Qs models (blue) derived in this study.

The geometry of the top of the laccolith layer, just because of its dome shape (see section in Figure 1) that in the central part of the island is hypothesized at depth lower than 1km (Carlino, 2012; Paoletti et al., 2013; Strollo et al., 2015; Di Giuseppe et al., 2017), is probably the reason of the higher standard deviations of the dispersion curve, observed at frequencies lower than $0.6 \mathrm{~Hz}$. This hypothesis is supported also by the frequencies of the peak (around $0.6 \mathrm{~Hz}$ ) of the stations located close or 
inside the resurgent block of Mt. Epomeo (IMTC, T1368, T1365 and T1366). In fact, moving from the center of the island to the coast, and especially toward the northern coast, we have observed that the frequency peak moves towards the low frequency (Figure 6), indicating a deepening of the laccolite top.

The obtained attenuation values (Qs) are reliable and comparable to results published for the nearby Campi Flegrei volcanic area, which is part of the same volcanic district comprising the Ischia island. In the case of Campi Flegrei, De Siena et al. (2017), using coda wave attenuation imaging, Qc, in the diffusive regime have found high-attenuation anomalies spatially correlated with the regions of highest structural complexities and cross faulting. In particular, the value of Qc $\sim 500$ at $3 \mathrm{~Hz}$, the lowest frequency for which Qc has been retrieved by the authors, is comparable with the Qs value obtained for the half space by our inversion process (Figure 10). Moreover, the low values of Qs obtained for the first two layers are coherent and comparable to those found at Stromboli volcano by Petrosino et al. (2012). These authors have interpreted the low values as due to poorly consolidated materials and levels of lava, which determine different stages of heterogeneity and crack density controlling the attenuation properties.

Summarizing, the results of the present study provide a quantitative estimate of the parameters that control the propagation of waves in a complex volcanic area, in which detailed knowledge of the elastic properties of the subsoil represents one of the background information to understand its dynamics. In particular, the definition of reliable velocity and attenuation structure allows to better understand both internal variations of the state of the volcano and its relative seismicity. They can further allow to better constrain the location of recorded earthquakes.

\section{Acknowledgements}

The authors thank the colleagues of the SISMIKO Coordination for supporting the activities and their availability for further interventions. We also thank the Negombo park, the Pera di Basso agritourism, the GraziaTerme Hotel, the Villa a Mare Hotel, the Iacono, Castaldi, Castagna and Madonna families for allowing the installation of temporary seismic stations. The development activities and the construction of the infrastructure were supported by the national Civil Protection Department. This research was partially supported by “FISR SALE” Project, funded by the MIUR.

\section{Data Availability}

The dataset related to this article may be available upon request to the author.

\section{References}

1. Acocella V., Cifelli F., Funiciello R., 2001.The control of overburden thickness on resurgent domes:insights from analogue models. Journal of Volcanology and Geothermal Research 111, 137-153.

2. Acocella V., Funiciello R., 1999. The interaction between regionaland local tectonics during resurgent doming: the case of theisland of Ischia, Italy. J. Volcanol. Geotherm. Res. 88, 109-123.

3. AGIP, 1987. Geologia e geofisica del sistema geotermico dei Campi Flegrei. Technical report. Settore Esplor. e Ric. Geoterm. Metodol. per l’Esplor. Geotermica. San Donato Milanese, Italy, pp. 1-23.

4. Aki K., 1957. Space and time spectra of stationary stochastic waves, with special reference to microtremors, Bull. Earthq. Res. Inst. 35, 415-456. 
5. Aki K., 1980. Scattering and attenuation of shear waves in the lithosphere. Journal of Geophysical Research: Solid Earth 85(B11), 6496-6504.

6. Aki, K. \& Chouet, B., 1975. Origin of coda waves: source, attenuation, and scattering effects, J. geophys. Res., 80, 3322-3342.

7. Arai H. and Tokimatsu K., 2005. S-wave velocity profiling by joint inversion of microtremor dispersion curve and horizontal-to-vertical (H/V) spectrum. Bull. Seism. Soc. Am. 95, 1766 - 1778.

8. Assefa S., McCann C., Sothcott J., 1999. Attenuation of P-and S-waves in limestones. Geophysical Prospecting 47(3), 359-392.

9. Bettig B., Bard P. Y., Scherbaum F., Riepel F., Cotton F., Cornou C., Hatzfeld D., 2001. Analysis of dense array noise measurements using the modified spatial auto-correlation method (SPAC): application to the Grenoble area. Boll. Geof. Teor. Applic. 42, 281-304.

10. Bonnefoy-Claudet S., Köhler A., Cornou C., Wathelet M., Bard P.Y., 2008. Effects of Love Waves on Microtremor H/V Ratio. Bull. Seism. Soc. Am. 98, No. 1, 288-300, doi: 10.1785/0120070063.

11. Boxberger T., Pilz M., Parolai S., 2017. Shear wave velocity versus quality factor: results from seismic noise recordings. Geophysical Journal International 210(2), 660-670, doi:http://doi.org/10.1093/gji/ggx161.

12. Brown R. J., Orsi G., de Vita S., 2008. New insights into Late Pleistocene explosive volcanic activity and caldera formation on Ischia (southern Italy). Bull Volcanol. 70(5), 583-603.

13. Capuano P., De Matteis R., Russo G., 2015. The structural setting of the Ischia Island caldera (Italy): first evidence from seismic and gravity data. Bull Volcanol. 77:79, https://doi.org/10.1007/s00445-015-0965-4.

14. Carlino S., 2012. The process of resurgence for Ischia Island (southern Italy) since 55ka: the laccolith model and implications for eruption forecasting. Bulletin of Volcanology 74 (5), 947-961.

15. Carlino S., Cubellis E., Luongo G., Obrizzo F., 2006. On the mechanics of caldera resurgence of Ischia Island (southern Italy). In: Troise C., De Natale G., Kilburn C. R. J., editors. Mechanisms of activity and unrest at large calderas, Geological society, vol. 269. London: Special Publications, 181-93.

16. Carlino S., Somma R., Troiano A., Di Giuseppe M.G., Troise C., De Natale G., 2014. The geothermal system of Ischia Island (southern Italy): Critical review and sustainability analysis of geothermal resource for electricity generation. Renewable Energy 62, 177-196.

17. Chiodini G., Avino R., Brombach T., Caliro S., Cardellini C., De Vita S., Frondini F., Granieri D., Marotta E., Ventura G., 2004. Fumarolic and diffuse soil degassing west of Mount Epomeo, Ischia, Italy, J. Volcanol. Geotherm. Res. 133, 291-309, doi:10.1016/S0377-0273(03)00403-7.

18. Costanzo M.R., Nunziata C., 2019. VS models in the historical centre of Naples (Southern Italy) from noise crosscorrelation. Journal of Volcanology and Geothermal Research 369, 80-94.

19. D'Auria L., Giudicepietro F., Tramelli A., Ricciolino P., Lo Bascio D., Orazi M., Martini M., Peluso R., Scarpato G., Esposito A., 2018. The Seismicity of Ischia Island. Seismological Research Letters; 89 (5), 1750-1760. doi: https://doi.org/10.1785/0220180084.

20. De Siena L., Amoruso A., Del Pezzo E., Wakeford Z., Castellano M., Crescentini L., 2017. Space-weighted seismic attenuation mapping of the aseismic source of Campi Flegrei 1983-1984 unrest. Geophys. Res. Lett. 44, 1740-1748, doi:10.1002/2017GL072507. 
21. de Vita S., Sansivero F., Orsi G., Marotta E., 2006. Cyclical slope instability and volcanism related to volcanotectonism in resurgent calderas: the Ischia island (Italy) case study. Eng. Geol. 86, 148-65.

22. de Vita S., Sansivero F., Orsi G., Marotta E., Piochi M., 2010. Volcanological and structural evolution of the Ischia resurgent caldera (Italy) over the past 10 k.y.. In Groppelli G. and Viereck-Goette L., eds., Stratigraphy and Geology of Volcanic Areas: Geological Society of America Special Paper 464, 193-241, doi: 10.1130/2010.2464(10).

23. Del Pezzo E., Ibanez J., Morales J., Akinci A., Maresca R., 1995. Measurements of intrinsic and scattering seismic attenuation in the crust. Bulletin of the Seismological Society of America, 85(5), 1373-1380.

24. Di Giulio G., Cornou C., Ohrnberger M., Wathelet M., Rovelli A., 2006. Deriving wavefield characteristics and shear-velocity profiles from two-dimensional small-aperture arrays analysis of ambient vibrations in a small-size alluvial basin, Colfiorito, Italy. Bull. Seismol. Soc. Am. 96, 1915-1933. doi:10.1785/ 0120060119.

25. Di Giulio G., Ercoli M., Vassallo M., Porreca M., 2020. Investigation of the Norcia basin (Central Italy) through ambient vibration measurements and geological surveys. Engineering Geology 267, 105501.

26. Di Giuseppe M.G., Troiano A., Carlino S., 2017. Magnetotelluric imaging of the resurgent caldera on the island of Ischia (southern Italy): inferences for its structure and activity. Bull Volcanol. 79:85, https://doi.org/10.1007/s00445017-1170-4.

27. Di Napoli R., Aiuppa A., Bellomo S., Brusca L., D’Alessandro W., Gagliano Candela E., Longo M., Pecoraino G., Valenza M., 2009. A model for Ischia hydrothermal system: Evidences from the chemistry of thermal groundwaters. J. Volcanol. Geotherm. Res. 186, 133-159, doi:10.1016/j.jvolgeores.2009.06.005.

28. Di Napoli R., Maratona R., Orsi G., Aiuppa A., Camarda M., De Gregorio S., Gagliano Candela E., Luzio D., Messina N., Pecoraino G., Bitetto M., de Vita S., Valenza M., 2011. The structure of a hydrothermal system from an integrated geochemical, geophysical, and geological approach: The Ischia Island case study. Geochem. Geophys. Geosyst. 12, Q07017, doi:10.1029/2010GC003476.

29. Dziewonski A., Hales A.L., 1972. Numerical analysis of dispersed seismic waves. Methods Comput. Phys. 39-85.

30. Ekström, G., Tromp, J., Larson, E.W.F., 1997. Measurements and global models of surface wave propagation. J. Geophys. Res. 102 (B4), 8137-8157. http://dx.doi.org/10.1029/ 96JB03729.

31. Famiani D., Brunori C.A., Pizzimenti L., Cara F., Caciagli M., Melelli L., Mirabella F., Barchi M. R., 2020. Geophysical reconstruction of buried geological features and site effects T estimation of the Middle Valle Umbra basin (central Italy). Engineering Geology 269, 105543.

32. Foti S., 2000. Multistation Methods for Geotechnical Characterization using Surface Waves. PhD dissertation, Politecnico di Torino, Italy

33. Foti S., Hollender F., Garofalo F., Albarello D., Asten M., Bard P.Y., Comina C., Cornou C., Brady Cox, Di Giulio G., Forbriger T., Hayashi K., Lunedei E., Martin A., Mercerat D., Ohrnberger M., Poggi V., Renalier F., Sicilia D., Socco V., 2017. Guidelines for the good practice of surface wave analysis: a product of the InterPACIFIC project. Bull Earthquake Eng 16, 2367-2420. https://doi.org/10.1007/s10518-017-0206-7.

34. Frankel A., McGarr A., Bicknell J., Mori J., Seeber L., Cranswick E., 1990. Attenuation of high-frequency shear waves in the crust: Measurements from New York state, South Africa, and southern California. Journal of Geophysical Research: Solid Earth, 95(B11), 17441-17457. 
35. Fukuchi T., Mizoguchi K., Shimamoto T., 2005. Ferrimagnetic resonance signal produced by frictional heating: A new indicator of paleoseismicity. Journal of Geophysical Research: Solid Earth, 110(B12).

36. Galluzzo D., La Rocca M., Margerin L., Del Pezzo E., Scarpa R., 2015. Attenuation and velocity structure from diffuse coda waves: Constraints from underground array data. Physics of the Earth and Planetary Interiors 240, 34 42.

37. Galluzzo D., Nardone L., Carandente A., Buonocunto C., Scarpato G., Marotta E., Milano G., Govoni A., Moretti M., 2019. Le attività del gruppo operativo SISMIKO in occasione del terremoto di Ischia Mw3.9 (Md4.0) del 21 Agosto 2017. Quaderni di Geofisica 154,1-28.

38. Galluzzo D., Nardone L., Manzo R., Di Maio R., Moretti M., Bianco F., Orazi M., 2018. Preliminary estimation of the shear wave velocity model of Ischia island using ambient noise broadband records. Proceedings of the $37^{\circ}$ GNGTS, 249-253.

39. Haong-Trong P., 1983. Some medium properties of the Hohenzollern graben (Swabian Jura, W. Germany) Inferred from Qp/Qs analysis. Physics of the Earth and Planetary Interiors 31, 119-131.

40. Havskov J., Ottemöller L., 2010. Array Processing, in Routine Data Processing in Earthquake Seismology Springer, 10.1007/978-90-481-8697-6_1.

41. Henstridge J., 1979. A signal processing method for circular arrays. Geophysics 44 : 179 - 184. doi:10.1190/1.1440959 .

42. Kramer S.L., 1996. Geotechnical earthquake engineering, Prentice Hall Inc., Upper Saddle River, New Jersey.

43. La Rocca M., Galluzzo D., Malone S., Mc Causland W., Del Pezzo E., 2010. Array analysis and precise source location of deep tremorin Cascadia. J. Geophys. Res. 115, B00A20, doi:10.1029/2008JB006041.

44. Lacoss R. T., Kelly E. J., Toksoz M. N., 1969. Estimation of seismic noise structure using arrays, Geophysics, 34, 21-38, doi:10.1190/1.1439995.

45. Lesage F., Heap M. J., Kushnir A., 2017. A generic model for the shallow velocity structure of volcanoes. Jour. Volcan. Geother. Resear. 365, 114-126.

46. Luongo G., Cubellis E., Di Vito M. A., Cascone E., 1995. L'isola d'Ischia: dinamica e struttura del M. Epomeo. In: Bonardi G, De Vivo B, Gasparini P, Vallario A, editors. Cinquant’anni di attività didattica e scientifica del Prof. Felice Ippolito. Napoli, Liguori Editore.

47. Maresca R., Damiano N., Nardone L., Di Vito M. A., Bianco F., 2014. A comparison of surface and underground array measurements of ambient noise recorded in Naples (Italy). Journal of Seismology 18(3), 385-400.

48. Molin P., Acocella V., Funiciello R., 2003. Structural, seismic and hydrothermal features at the border of an active intermittent resurgent block: Ischia Island (Italy). J. Volcanol. Geotherm. Res. 121(1), 65-81.

49. Nakahara H. 2012. Formulation of the spatial autocorrelation (SPAC) method in dissipative media. Geop. Jour. Inter. 190, 3, 1777-1783.

50. Nardone L., Esposito R., Galluzzo D., Margerin L., Calvet M., Bianco F., 2017. Diffuse Coda wavefield and seismic noise to investigate subsoil structures: the Campi Flegrei case. Proceedings of the 36 GNGTS 2017, 401-406.

51. Nardone L., Maresca R., 2011. Shallow velocity structure and site effects at Mt. Vesuvius, Italy, from HVSR and array measurements of ambient vibrations. B. Seismol. Soc. Am. 101(4), 1465-1477. doi:10.1785/0120100165. 
52. Nunziata C., Rapolla A., 1987. A gravity and magnetic study of the volcanic island of Ischia, Naples (Italy). J Volcanol Geotherm Res. 31, 333-344.

53. Obermann A., Hillers G., 2019. Chapter Two - Seismic time-lapse interferometry across scales, in Advances in Geophysics, Elsevier, Vol. 60, p. 65-143, https://doi.org/10.1016/bs.agph.2019.06.001, Editor(s): Cedric Schmelzbach.

54. Ohori M., Nobata A., Wakamatsu K., 2002. A comparison of ESAC and FK methods of estimating phase velocity using arbitrarily shaped microtremor arrays. Bull. Seismol. Soc. Am. 92 (6), 2323-2332.

55. Orazi M., Tramelli A., Augusti V., Bellucci Sessa E., Bobbio A., Brandi G., Buonocunto C., Capello M., Carandente A., Caputo A., De Cesare W., Di Lieto B., Esposito A., Galluzzo D., Giannuzzi R., Giudicepietro F., Lo Bascio D., Margheriti L., Marotta E., Martino C., Moretti M., Nardone L., Ricciolino P., Peluso R., Pinto S., Romano P., Scarpato G., Torello V., Castellano M., 2018. La rete sismica di Ischia dell’Osservatorio Vesuviano - INGV: evoluzione, configurazione attuale e performance. Proceedings of the 37 GNGTS, 261-265.

56. Orsi G., Chiesa S., 1988. The uplift of the Mt. Epomeo block at the island of Ischia (Gulf of Naples): geological and geochemical constraints. Eos. 69(44), 1473.

57. Orsi G., de Vita S., Di Vito M., Isaia R., Nave R., Heiken G., 2003. Facing volcanic and related hazards in the Neapolitan area. In: Heiken, G., Fakundiny, R, Sutter, J. (Eds) Earth Sciences in Cities, American Geophysical Union (Special Publication), Washington, 121-170.

58. Orsi G., Gallo G., Zanchi A., 1991. Simple-shearing block resurgence in caldera depression. A model from Pantelleria and Ischia. J. Volcanol. Geotherm. Res. 47, 1-11.

59. Paoletti V., D’Antonio M., Rapolla A., 2013. The structural setting of the Ischia Island (Phlegrean Volcanic District, southern Italy): inferences from geophysics and geochemistry. J. Volcanol. Geotherm. Res. 249, 155-73, https://doi.org/10.1016/j.jvolgeores.2012.10.002.

60. Paoletti V., Di Maio R., Cella F., Florio G., Motschka K., Roberti N., Secomandi M., Supper R., Fedi M., Rapolla A., 2009. The Ischia volcanic island (southern Italy): inferences from potential field data interpretation. J. Volcanol. Geotherm. Res. 179, 69-86.

61. Penta F., 1963. Sulle caratteristiche idrotermologiche dell'isola d'Ischia (Napoli). Rend. Acc. Lincei 34, 1-8.

62. Penta F., Conforto B., 1951. Risultati di sondaggi e di ricerche geominerarie nell'isola d'Ischia dal 1939 al 1943, nel campo del vapore, delle acque termali e delle 'forze endogene’ in generale. Ann. Geofis. 4, 159-191.

63. Petrosino S., Damiano N., Cusano P., Di Vito M. A., de Vita S., Del Pezzo E., 2012. Subsurface structure of the Solfatara volcano (Campi Flegrei caldera, Italy) as deduced from joint seismic-noise array, volcanological and morphostructural analysis. Geochemistry, Geophysicsand Geosystems 13(7), doi:10.1029/2011GC004030.

64. Picozzi M., Strollo A., Parolai S., Cakti E., Ozel O., Karabulut S., Zschau J., Erdik M., 2009. Site characterization by seimic noise in Istambul, Turkey. Soil Dynamics and Earthquake Engineering 29 (3), 469 - 482.

65. Poggi V., Fäh D., 2010. Estimating Rayleigh wave particle motion from three-component array analysis of ambient vibrations,. Geophysical Journal International 180(1), 251-267, https://doi.org/10.1111/j.1365-246X.2009.04402.x.

66. Prieto G. A., Lawrence J. F., Beroza G. C., 2009. Anelastic Earth structure from the coherency of the ambient seismic field. Journal of Geophysical Research: Solid Earth114(B7).

67. Rittmann A., 1930. Geologie der Insel Ischia. Z. f. Vulkanol. Erganzungsband. p. 6. 
68. Rittmann A., Gottini V., 1980. L’Isola d’Ischia - Geologia. Boll Serv Geol It. 101, 131-274.

69. Roth E. G., Wiens D. A., Zhao D., 2000. An empirical relationship between seismic attenuation and velocity anomalies in the upper mantle. Geophysical Research Letters 27(5), 601-604.

70. Sbrana A., Fulignati P., Marianelli P.C., Boyce A.J., Cecchetti A., 2009. Exhumation of an active magmatichydrothermal system in a resurgent caldera environment: the example of Ischia (Italy).J. Geol. Soc. 166(6):10611073.

71. Sbrana A., Marianelli P., Pasquini G., 2018. Volcanology of Ischia (Italy). Journal of Maps 14(2), 494-503, doi: 10.1080/17445647.2018.1498811.

72. Sbrana A., Toccaceli R.M., 2011. “Carta Geologica della Regione Campania - Foglio 464 - Isola di Ischia”, Progetto CARG Regione Campania - Assessorato Difesa del Suolo, Litografia Artistica Cartografica, Firenze.

73. Schweitzer J., Fyen J., Mykkeltveit S., Kværna T., 2012. Chapter 9: Seismic Arrays, in IASPEI New Manual of Seismological Observatory Practice, p. 52, ed. Bormann P., GeoForschungsZentrum, Potsdam.

74. Spica Z., Caudron C., Perton M., Lecocq T., Camelbeeck T., Legrand D., Piña-Flores J., Iglesias A., Syahbana D. K., 2015.Velocity models and site effects at Kawah Ijen volcano and Ijen caldera (Indonesia) determined from ambient noise cross-correlations and directional energy density spectral ratios. Journal of Volcanology and Geothermal Research 302, 173-189.

75. Strollo R., Nunziata C., Iannotta A., Iannotta D., 2015. The uppermost crust structure of Ischia (southern Italy) from ambient noise Rayleigh waves. Journal of Volcanology and Geothermal Research 297, 39-51.

76. Tibaldi A., Vezzoli L., 1998. The space problem of caldera resurgence: an example from Ischia Island, Italy. Geol. Rundsch. 87, 53-66.

77. Vanorio T., Prasad M., Patella D., Nur A., 2002. Ultrasonic velocity measurements in volcanic rocks: correlation with microtexture. Geophy. J. Int. 149, 22-36.

78. Vassallo M., Galluzzo D., Sapia V., Nardone L., Pischiutta M., Petrosino S., and the Emersito++ working group, 2018. Site effect studies following the $2017 \mathrm{Mw} 3.9$ Ischia earthquake: the Emersito++ Task Force activities. Geophysical Research Abstracts 20, EGU2018-16452-1.

79. Vezzoli L., 1988. Island of Ischia. Quaderni de "La ricerca scientifica”, CNR-PFG, 114, 10.

80. Wathelet M., Jongmans D., Ohrnberger M., 2004. Surface wave inversion using a direct search algorithm and its application to ambient vibration measurements. Near Surface Geophysics 2, 211-221.

81. Wathelet M., Jongmans D., Ohrnberger M., 2005. Direct inversion of spatial autocorrelation curves with the neighborhood algorithm. Bull. Seismol. Soc. Am. 95, 1787-1800.

82. Wathelet M., Jongmans D., Ohrnberger M., Bonnefoy-Claudet S., 2008. Array performances for ambient vibrations on a shallow structure and consequences over Vs inversion. J. Seismol. 12, 1-19, doi:10.1007/s10950-007-9067-x. 